\title{
Food insecurity measurement and indicators
}

\section{Indicadores e medidas de insegurança alimentar}

\author{
Rafael PÉREZ-ESCAM ILLA ${ }^{1}$ \\ Ana Maria SEGALL-CORRÊA ${ }^{2}$
}

The United Nations define food security as "People having at all times, physical, social and economic access to sufficient, safe and nutritious food which meets their dietary needs and food preferences for an active and healthy life." There are five methods that are commonly applied in national surveys that can be used to assess food insecurity. Of these, four are indirect or derivative measures of food insecurity (United Nations Food and Agriculture Organization method, household expenditure surveys, dietary intake assessment and anthropometry). The only method that represents a fundamental or direct measure of food insecurity is the one based on experience-based food insecurity scales. All the methods complement each other and the method of choice depends on the question being answered and the economic and logistical resources available to collect valid data. All the methods have serious measurement error issues that can be reduced by fully understanding the principles underlying them and the use of highly trained and standardized research field workers. As show $\mathrm{n}$ in Brazil, the use of experience-based food insecurity measurement scales for mapping, targeting, and understanding the determinants and consequences of food insecurity is very promising. Thus, we recommend the Latin American and Caribbean Region to work towards the adoption of a single regional module that can be adapted to the local contexts based on qualitative cognitive research follow ed by quantitative confirmation of the scale's psychometric properties. The Brazilian experience-based food insecurity measurement project is likely to provide useful insights to other countries in the region.

Indexing terms: Bias (Epidemiology). Caribbean region. Food insecurity. Latin America.

As Nações Unidas definem Segurança Alimentar como a situação em que "as pessoas têm a todo tempo, acesso físico, social e econômico a alimentação segura, nutritiva e que atende suas necessidades dietéticas, com alimentos de sua preferência para uma vida ativa e saudável". Existem cinco métodos comumente utilizados em inquéritos nacionais para avaliação de insegurança alimentar. Desses, quatro são indiretos, ou medidas derivadas de insegurança alimentar (método da Organização das Nações Unidas para Agricultura e Alimentação,

1 University of Connecticut, Connecticut NIH EXPORT Center of Excellence for Eliminating Health Disparities, Among Latinos, Storrs CT 06269-4017 USA. Correspondência para/Correspondence to: R. PÉREZ-ESCAMILLA. E-mail: ४rafael.perez-escamilla@uconn.edu>.

2 Universidade Estadual de Campinas, Faculdade deCiências M édicas, Departamento de M edicina Preventiva e Social. Campinas, SP, Brazil. 
pesquisas de despesas familiares, avaliação de consumo e antropometria). 0 único método para medida direta ou fundamental de insegurança alimentar é representado por uma escala fundamentada na experiência de insegurança alimentar. Todos os métodos complementam-se mutuamente, o de escolha dependerá das perguntas a serem respondidas e dos recursos econômicos e logísticos disponíveis para coletar informações válidas. Todos os métodos possuem problemas sérios de erros de medida, que poderão ser reduzidos pelo conhecimento dos princípios nos quais estão baseados, além do envolvimento de pesquisadores de campo bem capacitados e padronizados. É promissor, como foi mostrado no Brasil, o uso de escala de medida baseada na experiência de insegurança alimentar, para mapear, identificar populações vulneráveis, compreender seus determinantes e conseqüências. Por essas razões, se recomendam, para a América Latina e o Caribe, trabalhos visando à adoção de instrumento regional único, adaptado aos contextos locais, a partir de investigações cognitivas qualitativas, seguidas de pesquisas de confirmação quantitativas das propriedades psicométricas das escalas. A experiência brasileira do projeto de medida de insegurança alimentar, provavelmente, oferecerá subsídios idéias úteis para outros países da região.

Termos de indexação: Viés (Epidemiologia). Região do Caribe. Insegurança alimentar. America Latina.

\section{IN TRO D U C TIO N}

The United Nations define food security as "People having at all times, physical, social and economic access to sufficient, safe and nutritious food which meets their dietary needs and food preferences for an active and healthy life". Over a billion people live under conditions of extreme poverty (i.e., earning less than US\$1 dollar per day). And it is estimated that 800 million people worldwide do not have access to sufficient amounts of food and hundreds of millions more do not have access to nutritional foods.

Household food security is a major determinant of nutrition security that can only be fully understood through a multi-level analysis taking into account global, national/regional, as well as local, household and individual-level factors $^{1,2}$ (Figure 1).

Nutrition security is a process that can be understood at the organism level as it is achieved when the cells and the tissues and organs that form the human body are properly nourished. Nutrition security is the product of food security and health security and the interrelationship between the two. Thus, nutrition security is derived from access to both a healthy diet and to preventive and curative healthcare. Both food security and health are strongly linked with available household income. Another factor that influences food security is the availability of a variety of nutritious foods at the local, regional, and national level. The availability of foods at the national level depends on local production for local consumption, as well as on the ability to import a variety of healthy and nutritious foods. Thus, a stable and sustainable global food supply is essential for ensuring food security. In sum, household food security and the individual's nutrition security depend on local, regional, national, and global factors. The following section presents the most commonly used food insecurity assessment methods. These methods were identified

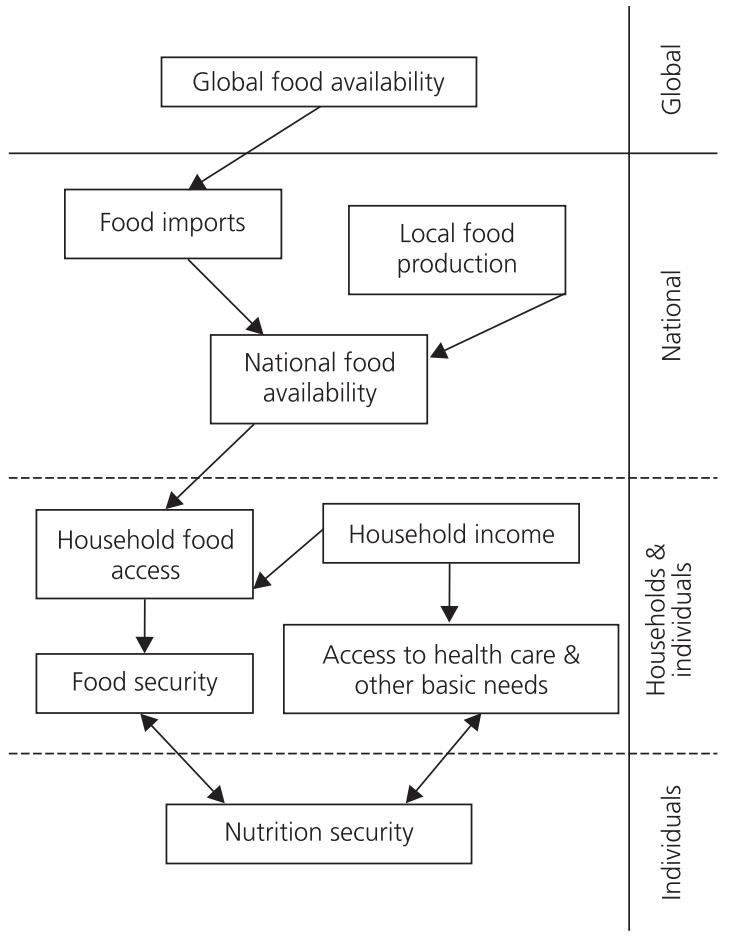

Figure 1. Food and nutrition security distal, intermediate and proximal determinants. Conceptual framework adapted with slight modifications from Smith ${ }^{1}$.

Nota: Frankenberg et al. ${ }^{2}$ 
by: a) reviewing United Nations agencies documents as these agencies are most involved compiling food insecurity assessments worldwide, and b) reviewing food insecurity assessment documents published during the last decade.

\section{Methods for measuring food security}

There are five commonly used methods that can be used to assess food security ${ }^{3}$ (Chart 1): i) the Food and Agriculture Organization (FAO) method for estimating calories available per capita at the national level; ii) household income and expenditure surveys; iii) individual's dietary intake; iv) anthropometry; and v) experience-based food insecurity measurement scales.

\section{The FAO method}

This method estimates calories per capita at the country level using Food Balance Sheets and energy intake variance data derived from household income and expenditure surveys. Countries need the following information to be able to apply this method: i) total calories available in year of interest; ii) number of people living in country in year of interest; iii) coefficient of variation of caloric intake to generate the energy intake distribution curve; iv) cut-off point to estimate the proportion of the population falling under the minimum per capita average caloric requirement.

\section{Advantages}

The main advantages of this method are that: i) almost all countries generate the data needed and estimate their daily per capita caloric availability; ii) estimates are frequently updated thus allowing the national, regional, and global food insecurity trends across time to be examined and compared; iii) the method is inexpensive.

\section{Disadvantages}

The FAO method has several limitations including: i) dietary quality is not taken into account; ii) the national average per capita calo ric intake does not allow for understanding the intracountry caloric distribution as a function of household characteristics; iii) method assumes that caloric consumption above minimum caloric threshold indicates food security, when in fact obesity has become a problem among the poor with excessive caloric consumption being associated with mild to moderate levels of food insecurity ${ }^{4}$; iv) high degree of measurement error in numerator (balance sheets provide data on the amount of calories available but not necessarily consumed) and denominator (i.e., number of inhabitants living in the country in the year of origin). Overall, the origin of data used by countries is sometimes difficult to understand and of questionable validity, and there is little standardization and quality control across countries; v) establishing an average per capita caloric requirement cut-off point has several conceptual weaknesses as in reality it is a function of physical activity levels, gender and age, among other factors.

\section{Household income and expenditure surveys}

This method is based on interviewing respondents in their households. Respondents provide information on the amount of money that they spend on food and other necessities. Different time reference periods have been used including the week(s) or month(s) preceding the survey. The following inputs are needed to be able to take full advantage of this method: i) quantity of food bought (or expenditures) and costs associated with different foods consumed within and outside the house; ii) foods received by any household member as either a gift or as payment for work, goods or services; iii) foods grown for consumption by household members. This method estimates calories consumed on average per household member per day, making it essential to have access to culturally appropriate and valid food composition tables. 
Chart 1. Derived and fundamental food insecurity measures.

\begin{tabular}{|c|c|c|c|}
\hline Method & Principles & Advantages & Disadvantages \\
\hline \multicolumn{4}{|l|}{ Derived measures } \\
\hline FAO method & $\begin{array}{l}\text { - Outcome: national calories } \\
\text { available per capita per day } \\
\text { - Inputs: food balance sheets, } \\
\text { energy intake coefficient of } \\
\text { variation, single cut-off point } \\
\text { to estimate at-risk population }\end{array}$ & $\begin{array}{l}\text { - Inexpensive } \\
\text { - Applied worldwide on } \\
\text { annual basis }\end{array}$ & $\begin{array}{l}\text { - Does not identify at-risk households } \\
\text { or individuals } \\
\text { - Dietary quality not taken into account } \\
\text { - High measurement error } \\
\text { - Low standardization on data } \\
\text { collection methods across countries } \\
\text { - Evidence-base of cut-off point is } \\
\text { questionable }\end{array}$ \\
\hline $\begin{array}{l}\text { Household expenditure } \\
\text { surveys }\end{array}$ & $\begin{array}{l}\text { - Outcomes: caloric intake per } \\
\text { capita per household, dietary } \\
\text { variety score } \\
\text { - Inputs: money spent on food } \\
\text { and other needs, foods } \\
\text { consumed and market value, } \\
\text { reference time period, food } \\
\text { composition tables to convert } \\
\text { food expenditures and } \\
\text { consumption into energy } \\
\text { intake }\end{array}$ & $\begin{array}{l}\text { - Identifies vulnerable } \\
\text { households } \\
\text { - Can take into account } \\
\text { dietary quality } \\
\text { - Used for evaluating } \\
\text { national anti-poverty and } \\
\text { assistance programs }\end{array}$ & $\begin{array}{l}\text { - Measures food available but not } \\
\text { necessarily consumed during period } \\
\text { of interest (periodicity bias) } \\
\text { - Difficult to estimate foods consumed } \\
\text { outside the household, fed to animals, } \\
\text { exchanged as gifts or payment of } \\
\text { work } \\
\text { - Difficult to standardize methodology } \\
\text { across countries } \\
\text { - Expensive and logistically difficult } \\
\text { - Data usually not available annually }\end{array}$ \\
\hline Dietary intake & $\begin{array}{l}\text { - Outcomes: Individual's food } \\
\text { group intake counts, nutrient } \\
\text { intake } \\
\text { - Inputs: } 24 \text {-hour recalls, FFQ, food } \\
\text { records, food composition } \\
\text { tables, known nutrient } \\
\text { requirements, reference time } \\
\text { period }\end{array}$ & $\begin{array}{l}\text { - Measures actual food } \\
\text { consumption } \\
\text { - Can assess short medium } \\
\text { and long term food } \\
\text { intake } \\
\text { - Deals with both dietary } \\
\text { quality and quantity } \\
\text { - Identifies at-risk } \\
\text { households and } \\
\text { individuals }\end{array}$ & $\begin{array}{l}\text { - Memory "recall" bias } \\
\text { - High intra-subject variability in food } \\
\text { and nutrient intakes } \\
\text { - Difficult to assess portion sizes } \\
\text { - Food composition tables need to be } \\
\text { of high qualityand culturallyappropriate } \\
\text { - Uncertainty about human } \\
\text { requirements for most nutrients } \\
\text { - High cost especially for inclusion of } \\
\text { 24-hour recalls in national surveys } \\
\text { - National data unavailable annually }\end{array}$ \\
\hline Anthropometry & $\begin{array}{l}\text { - Outcome: \% population } \\
\text { malnourished } \\
\text { - Inputs: weight height, other } \\
\text { body dimensions }\end{array}$ & $\begin{array}{l}\text { - Highly standardized } \\
\text { - Evidence-based cut-off } \\
\text { points } \\
\text { - Inexpensive } \\
\text { - Frequently applied in } \\
\text { national surveys }\end{array}$ & $\begin{array}{l}\text { - Nutritional status indicator } \\
\text { - Fl-obesity relationship difficult to } \\
\text { interpret }\end{array}$ \\
\hline \multicolumn{4}{|l|}{ Fundamental measure } \\
\hline $\begin{array}{l}\text { Experience-based food } \\
\text { insecurity scales }\end{array}$ & $\begin{array}{l}\text { - Outcome: Household level of } \\
\text { food insecuritylnputs: scale } \\
\text { containing items representing } \\
\text { the conceptual and } \\
\text { multidimensional nature of Fl, } \\
\text { algorithm to convert scale } \\
\text { scores into Fl categories }\end{array}$ & $\begin{array}{l}\text { - Fundamental measure of Fl } \\
\text { - HFSSM and adaptations } \\
\text { valid across diverse socio- } \\
\text { cultural settings } \\
\text { - Captures the physical and } \\
\text { psycho-emotional } \\
\text { dimensions of Fl } \\
\text { - Low cost allowing for } \\
\text { decentralization }\end{array}$ & $\begin{array}{l}\text { - Doesnot capturefood safety dimension } \\
\text { - Different reference time periods and } \\
\text { frequency response options needed } \\
\text { in different settings } \\
\text { - Difficult to standardize cut-off points } \\
\text { across regions/countries } \\
\text {-"Benefit" bias }\end{array}$ \\
\hline
\end{tabular}

FFQ: food frequency questionnaire; Fl: food insecurity; HFSSM: US Household Food Security Survey Measure; FAO: Food and Agriculture Organization. 


\section{Advantages}

There are several advantages associated with this method: i) it allows for the identification of households at risk of food insecurity, thus in addition to mapping from the local to the national level, the determinants and consequence of food insecurity can be examined; ii) it collects dietary quality data that can be taken into account to understand the dimension of the food insecurity construct; iii) it can be used to evaluate national food and nutrition, and anti-poverty programs.

\section{Disadvantages}

This method has the following limitations: i) it measures the amount of food available but not necessarily the amount of food consumed within the timeframe of interest, for example, it is quite difficult to measure the amount of food wasted, consumed by guests or fed to household animals; ii) it is difficult to estimate the amount of food consumed outside the household as many people can report how much they spend but have a difficult time reporting accurately the foods consumed outside the household; given the frequent consumption by the majority of the world's population of many different kinds of street foods and fast foods, accurately recalling this information is indeed a daunting task; iii) periodicity in food acquisition can bias the results, for example, it is possible that household members consumed foods that were purchased before the reference period, thus they would be omitted; likew ise foods may have been purchased but may have not been consumed during the period of interest, in this instance these foods would be included in the estimate when in reality they should have not; iv) different countries use different methods for data collection and estimation of key parameters, making it difficult, if not impossible, to compare estimates across countries and regions; v) the conversion of the estimated foods available to the household into caloric intakes involves making major assumptions, thus accepting a high degree of measurement error in the key indicator derived from this method; vi) the method is expensive and requires major input from interdisciplinary teams making it difficult to apply nationally on an annual basis.

\section{Individual's dietary intake}

The individual's dietary intake can be measured through different methods including: i) 24-hour recall; ii) food frequency questionnaires; iii) food records kept by individuals or by an observer. All dietary intake methods need to make use of a reference time frame. Whereas some of the methods rely on the memory of participants (24-hour recall, food frequency questionnaire), others rely on the recording of foods, as they are consumed, by the study participant, a proxy or an observer. Portion size estimations can rely on assisted memory (e.g. using food models) or foods can actually be weighted before and right after consumption. These portion size estimations are needed to estimate food group counts as well as nutrient intakes, the latter provided that culturally appropriate and valid food composition data bases are available. Lastly, to interpret the nutrient intake findings it is important to have cut-off points for determining the proportion of the sample or population at risk of deficiencies for different nutrients.

\section{Advantages}

In relationship to the previous methods discussed, dietary intake assessment has some unique, as well as common, advantages: i) it measures food consumption directly and not only food availability; ii) it addresses both dietary quality (macro and micronutrients) and caloric intakes at the individual level; iii) it allows for mapping from the local to the national level, and the determinants and consequences of food insecurity at the individual level can be examined; this is important for understanding, for example, intra-household food consumption patterns and how it is influenced 
by gender; iv) different dietary intake methods can be used to understand recent (e.g., 24-hour recall) vs. longer term dietary intake patterns (e.g. food frequency questionnaires).

\section{Disadvantages}

By far the methods most commonly used in national dietary intake surveys are the 24-hour recall and the food frequency questionnaire. Both methods rely heavily upon the memory of respondents leading to substantial measurement error even when people are asked to recall what they ate the day before, as in the case of the 24hour recall. In this instance, respondents also need to recall and accurately report the method of preparation of different meals (e.g. boiling, frying, roasting), spices and other ingredients used and to provide the recipes followed with mixed dishes. The assessment of 24-hour recall portion size estimations is as much an art as a science, as it involves participants recalling not only what they ate, but also how much of it. All of these methodological challenges can lead to an unacceptably high measurement error, especially when interviewers are not fully trained and standardized against each other and the lead supervisor. In addition, 24-hour recalls need to be applied in different occasions to the same individuals to be able to have a reasonable estimate of their usual food and nutrient intakes. Single 24-hour recalls cannot meet this need as the intra-subject day-to-day variability in food (and nutrient) intake is very high. In sum, the first major disadvantage of the 24-hour recall and other dietary intake methods is a very high level of measurement error.

The cost of applying 24-hour recalls in national survey is high. Each 24-hour recall takes at least 20 to 30 minutes to apply (depending on the amount of food consumed by the respondent) by a highly trained and experienced interviewer. Likewise, entering the 24 hour-recall data into the software containing the food composition databases needed to convert food intake into nutrient intakes, requires a high level of training and skill.

The nutrient and phytochemical food composition data is usually based on a few samples of each food product and does not take into account the bioavailability of the nutrients in the foods. Nutrient bioavailability is heavily affected by other components in the food matrix, the method of food preparation as well as the individual's health and physiological status. Thus, this becomes another major source of measurement error when estimating nutrient intakes.

Last but not least, estimating the likelihood of nutrient deficiencies relies on cut-off points that are tentative at best, and that are likely to change as more scientific evidence accumulates.

In sum, on the one hand dietary intake methods have important advantages for estimating the risk of food and nutritional insecurity of individuals. On the other hand, applying these methods is very costly, requires very skilled and highly trained personnel, specialized software, and even then, we need to accept a very high level of measurement error and potential misclassification. This is likely to explain, at least in part, why countries have gone for years, and in some instances decades, without conducting national dietary intake surveys.

\section{Anthropometry}

Anthropometry is defined as the measurement of size, weight, body proportions and ultimately the composition of the human body. Anthropometric indicators measure the impact of both food insecurity and health status on the nutritional status of individuals. The anthropometric indicators most commonly used in national surveys are based on weight and height (or length) of infants, young children, youth and adults. The interpretation of the adequacy of the anthropometric indicators is based on well established cut-off points. 


\section{Advantages}

Weight and height measurements are highly standardized and are highly reproducible across individuals doing the anthropometry and across settings. In addition the cost of doing the measurements is relatively low making it a very popular method in national surveys worldwide. The cut-off points used to interpret anthropometric measures are relatively stronger on their evidencebased compared to the cut-off points for establishing the adequacy of nutrient intakes. Anthropometry also allows for mapping nutritional security from the local to the national level and for understanding trends, determinants and consequences of malnutrition at the individual level.

\section{Disadvantages}

There are two main limitations when using anthropometric indicators as proxies for food insecurity. First, these indicators are an indirect approximation to food insecurity, as they measure nutritional status which is the result of the interaction between food (in)security and health status. Second, the interpretation of the relationship between food insecurity and obesity is complex, as there is growing evidence that whereas severe food insecurity leads to wasting, mild to moderate food insecurity may lead to obesity ${ }^{4}$. Individuals in this food insecurity category may rely heavily on cheap high-energy low nutrient density foods.

\section{Food insecurity experience-based measurement scales}

All the methods discussed above are derived or indirect measurements of the phenomena of interest (i.e., food insecurity). Fortunately over the past two decades there have been major advances on the fundamental measurement of household food insecurity using scales based on the perception or experience reported by the affected individuals. The foundational work that led to this effort was conducted by researchers from Cornell and Tufts Universities in the United States of America (USA) and by a non governmental organization ${ }^{5,6}$. Because the Cornell researchers fully documented the process, this section concentrates first on their work followed, by how the US Department of Agriculture ended up coordinating the process that led to the US Household Food Security Survey M easure (HFSSM ) based on the experience-based scales previously developed in the USA. This section concludes with the international experience adapting, validating, and applying the HFSSM and other experiential scales in very diverse socio-cultural contexts.

In the early 80's, Cornell researchers used qualitative research methods to better understand the food insecurity experience among low-income women living in upstate New York ${ }^{5}$. The qualitative results were then translated into a 10item scale that dealt with the following dimensions of the food insecurity construct: i) psychoemotional, ii) dietary quality, and iii) dietary quantity. The Cornell scale focuses on lack of access to nutritional foods or enough amounts of foods because of lack of money. Questions are usually answered by a respondent who is in charge or well informed about food acquisition and food intake patterns in the household. An algorithm based on the questions that are answered affirmatively (i.e., describing experiencing the negative situation sometimes or frequently) was developed to classify the household as either food secure or as food insecure with or without hunger. The items are ordered following the assumption (established based on the qualitative research that preceded it) that chronic food insecurity results in a process managed at the household level that involves predictable coping mechanisms or adaptations specific to the degree of severity of the food insecurity challenge. In other words, a food secure household may first experience a negative event, such as the loss of employment of the head of the household, that triggers a state 
of anxiety and worry in the household reflecting a feeling of uncertainty about how to keep food on the table in the near future. If the situation does not get corrected the household will start using strategies to "extend" the food so that it lasts longer, e.g. adding water to milk, consuming artificial sweetened drinks instead of $100 \%$ fruit juices, consuming more pasta or rice instead of legumes or other vegetables. At this stage, households are likely to sacrifice their dietary quality to sustain their caloric needs, and in some instances this approach may even lead to excessive caloric consumption. If the food insecurity process continues moving forward, household members will start eventually reducing the amount of foods needed to sustain their caloric needs, leading to hunger first in adults and then children.

In the 90's, the US Department of Agriculture took the leadership coordinating the development of the HFSSM based on the strong evidence-based effort that led to the Cornell scale as well as the scale developed for the Community Childhood Hunger Identification Project (CCHIP) ${ }^{7}$. The product of this consultative consensus process was the national application of the HFSSM in 1995. HFSSM has 15 items and 3 subitems and is grounded on the theory and logic followed by the Cornell scale. There were, however, major changes on the algorithm used to classify the households into the different severity levels of food (in)security. A summative score is generated for each household based on the total number of questions that were answered affirmatively, thus ranging from 0 to 18 in households with children. Households are then classified as either food secure or in one of three levels of food insecurity based on cut-off points established using scale item response Rasch modeling techniques. The HFSSM or its shorter version has been applied through the Census Population Survey, The National Health and Nutrition Survey (NHANES), and by numerous researchers seeking to understand the causes and consequences of food insecurity. Overall, in the
US population the HFSSM has shown excellent predictive validity and its psychometric behavior indicates that items fit and discriminate among households very well. Likewise, the scale items' severity loads and response patterns follow quite well the theoretical expectations.

\section{International experience}

Researchers have devoted substantial efforts to adapt, validate and apply the HFSSM and other experience-based scales in diverse countries. Coates et al. ${ }^{8}$ recently compared and summarized the content of 22 different experiential food insecurity scales used in 15 different countries. Scale-item response comparative analyses of 11 studies confirmed the presence of the following domains across cultures: i) uncertainty and worry about food, ii) inadequate food quality and iii) insufficient food quantity. The subdomains of food safety and meal pattern disruption were also identified in some, but not all studies. One of the studies included in the paper by Coates et al. was the adaptation and validation of the HFSSM in Brazil. This project is described in more detail below as it was based on a systematic evidence-based multisectoral and interdisciplinary mixed-methods approach, that led to the national adoption and application of the scale $e^{9-13}$.

The process in Brazil began in 2003 with focus groups conducted in 4 urban areas to discuss key food security concepts and each of the items included in the HFSSM. Results from these discussions led to the development of an adapted version of HFSSM now known as the Brazilian Food Insecurity Scale (EBIA) that was subsequently tested in all four urban areas by applying it to samples ranging between 125 and 200 households each (Chart 2). Cronbach's alpha was $>0.90$ in all samples indicating a strong internal consistency of the scale. EBIA had strong criterion validity as the level of severity of food insecurity was strongly and inversely associated with household income and with the likelihood of daily consumption of 
nutritious foods such as fruits and vegetables and high quality protein foods ${ }^{9-11}$. This outstanding psychometric performance was confirmed through item response Rasch modeling in a subsequent study conducted with a representative sample of Campinas ${ }^{13}$. The work in the urban areas was replicated in 5 rural areas with similar results9-12. As consequence, the lead researchers recommended the Federal Government to consider the introduction of EBIA in national surveys. In 2004, EBIA was applied to 120,000 household as part of the annual National Household Survey (PNAD). The outstanding psychometric behavior and validity of the scale was confirmed in this representative sample leading, for the first time, to the mapping of the problem of food insecurity and hunger and identification of risk factors in a country as complex, large, and diverse as Brazil1 ${ }^{14}$.

In addition to Brazil, scales derived from HFSSM have also been tested and validated in countries as diverse as M exico, Senegal, Trinidad and Tobago, Bolivia, Burkina Faso, and the Philippines ${ }^{15-18}$. In all these instances, as in the case of Brazil the scale performed adequately. Furthermore, the scale items' severity rankings are very similar across countries, indicating that individuals across cultures experience and interpret food insecurity very similarly. In some countries like Venezuela and Colombia8,19 scales derived from sources other than HFSSM have been used, although results have not been as encouraging as with the HFSSM-derived scales. For this reason the recently recommended international Household Food Insecurity Access Scale (HFIAS) draws heavily from HFFSM 20.

\section{Advantages}

Experience-based food insecurity measurement scales offer several advantages: i) it is the only fundamental method that measures directly the phenomenon of interest based on the food insecurity experience as perceived by the affected individuals; ii) it captures not only the physical but also the psychosocial dimensions of food insecurity; iii) the method can be used for mapping and understanding causes and consequences of food insecurity and hunger using the household as the unit of analysis; iv) data collection, processing and analysis is straightforward and relatively inexpensive, allowing for the decentralization of data collection efforts; v) the same scale, with language adapted to the local context, based on cognitive qualitative research, may be applied in very diverse sociocultural settings yielding valid and predictable results.

\section{Disadvantages}

There are several limitations that need to be taken into account: i) most experience-based food insecurity scales do not have questions on issues related to water access; ii) most experiential food insecurity scales do not have questions on issues related to food and water safety hazards caused by microbial and other environmental contaminants; in a number of countries respondents have expressed concerns of not knowing the origin of the food and its likelihood of being contaminated ${ }^{8,10}$. Clearly in the minds of people, food safety is part of the food security construct, iii) establishing cut-off points for classifying households into different levels of food insecurity is not a simple task; it is unknown if the cut-off points will end up being similar or not in different countries, iv) timeframe of reference (e.g. previous month (Senegal ${ }^{17}$ ), previous 3 months $\left(\right.$ Brazil $^{10}$, Mexico $\left.^{15}\right)$, previous year (USA $)^{7}$ ) and frequency response options need to differ in different countries as the prevalence, frequency, and intensity of the problems captured by the scale items is very sensitive to the social and economic development of nations, thus making it difficult to compare results across world regions; v) the scale may loose its validity if it is used for determining eligibility into food and social assistance programs; this is because the perception of benefit can seriously bias how individuals respond to the scale questions. 
Chart 2. Brazilian food insecurity scale (EBIA) items in Portuguese and their corresponding English back-translation ${ }^{\mathbf{1 , 2}}$.

\begin{tabular}{|c|c|}
\hline Item & Portuguese nos últimos 3 meses.... \\
\hline 1 & $\begin{array}{l}\text { A(o) senhora(sr) teve preocupação de que a comida na sua casa } \\
\text { acabasse antes que a(o) senhora(sr) tivesse condição de comprar ou } \\
\text { receber mais comida? }\end{array}$ \\
\hline 2 & $\begin{array}{l}\text { A comida acabou antes que a(o) senhora(sr) tivesse dinheiro para } \\
\text { comprar mais? }\end{array}$ \\
\hline 3 & $\begin{array}{l}\text { A(o) senhora(sr) ficou sem dinheiro para ter uma alimentação saudá- } \\
\text { vel e variada? }\end{array}$ \\
\hline 4 & $\begin{array}{l}\text { A(o) senhora(sr) teve que se arranjar com apenas alguns alimentos } \\
\text { porque o dinheiro acabou? }\end{array}$ \\
\hline $5^{*}$ & $\begin{array}{l}\text { A(o) senhora(sr) não pôde oferecer a(s) suas criança/adolescente(s) } \\
\text { uma alimentação saudável e variada porque não tinha dinheiro? }\end{array}$ \\
\hline $6^{*}$ & $\begin{array}{l}\text { A(s) criança/adolescente(s) não comeu (comeram) quantidade sufi- } \\
\text { ciente porque não havia dinheiro para comprar a comida? }\end{array}$ \\
\hline
\end{tabular}

$7 \quad \mathrm{~A}(0)$ senhora(sr) ou algum adulto em sua casa diminuiu, alguma vez, a quantidade de alimentos nas refeições ou pulou refeições, porque não havia dinheiro suficiente para comprar a comida?
$A(0)$ senhora(sr) alguma vez comeu menos do que achou que devia porque não havia dinheiro o suficiente para comprar comida?

$A(0)$ senhora(sr) alguma vez sentiu fome mas não comeu porque não podia comprar comida suficiente?

$A$ (o) senhora(sr) perdeu peso porque não tinha dinheiro suficiente para comprar comida?

A(o) senhora(sr) ou qualquer outro adulto em sua casa ficou, alguma vez, um dia inteiro sem comer ou, teve apenas uma refeição ao dia, porque não havia dinheiro para a comida?

$\mathrm{A}$ (0) senhora(sr) alguma vez diminuiu a quantidade de alimentos das refeições de sua(s) criança/adolescente(s), porque não havia dinheiro o suficiente para comprar a comida?

Alguma vez $\mathrm{a}(0)$ senhora(sr) teve de pular uma refeição da(s) criança/adolescente(s) porque não havia dinheiro para comprar a comida?

Sua(s) criança/adolescente(s) teve (tiveram) fome mas a(o) senhora(sr) simplesmente não podia comprar mais comida?

Sua(s) criança(s) ficou (ficaram) sem comer por um dia inteiro porque não havia dinheiro para comprar a comida?
English during the last 3 months...

Were you worried that you would run out of food before being able to buy or receive more food?

Did you run out of food before having money to buy more?

Did you run out of money to have a healthy and varied diet?

Did you have to consume just a few foods because you ran out of money?

Were you unable to offer your children/adolescents a healthy and varied diet because you did not have enough money?

Did any of the children/adolescents not eat enough because there was not enough money to buy food?

Did you or any adult in your household ever reduce the size of meals or skip meals because there was not enough money to buy food?

Did you ever eat less than what you thought you should because there was not enough money to buy food?

Did you ever feel hungry but did not eat because there was not enough money to buy food?

Did you lose weight because you did not have enough money to buy food?

Did you or any other adult in your household ever go without eating for a whole day or just have one meal in a whole day because there was not enough money to buy food?

Did you ever reduce the size of meals of your children/ adolescents because there was not enough money to buy food?

Did your children/adolescents ever have to skip a meal because there was not enough money to buy food?

Were your children/adolescents ever hungry but you just could not buy more food?

Did your children go without food for a whole day because there was not enough money to buy food?

*items only asked in households with members 18 years old or younger; ${ }^{1}$ Source: reference 10 . For all items, except item \# 10, an affirmative response was followed by asking 'How often did this happen?' Response options were: (a) almost every day, (b) in just a few days, (c) in only 1 or 2 days, (d) does not know or refuses to answer. An affirmative response for item 10 was followed by asking 'How much weight did you lose?' 2Response options were: (a) little, (b) some, (c) a lot, (d) does not know or refuses to answer.

\section{CONCLUSIO N}

There are five methods that are commonly used in national surveys to assess food insecurity. Of these, four are indirect or derivative measures of food insecurity (FAO method, household expenditure surveys, dietary intake assessment and anthropometry). All the methods complement each other and none should be considered superior over another one. In most instances, the method of choice depends on the question that needs to be answered, as well as the budget available to 
conduct the assessment. Ideally, food security assessments should be based on the application of several of these methods. This way, different dimensions from the food insecurity problem can be addressed in the same survey or study.

The only method that represents a fundamental or direct measure of food insecurity is the one based on experience-based food insecurity measurement scales. Whereas the FAO method concentrates on food insecurity risk at the national level, the remaining methods discussed concentrate on assessing the risk at the individual or household level. Likewise, whereas some of the derivative measures assess the determinants (i.e., dietary intake, food expenditures), others measure the consequences of food insecurity (i.e., anthropometry). Thus, as indicated above, all the methods complement each other and the method of choice depends on the question being answered and the economic and logistical resources available to collect valid data. All the methods have serious measurement error issues that can be attenuated by fully understanding the principles underlying them and the use of highly trained and standardized research field workers.

Even though work remains to be done ${ }^{8,21}$, the use of experience-based food insecurity measurement scales is very promising and can greatly complement the information provided by the other food security assessment methods. Thus, we recommend the Latin American and Caribbean Region to work towards the adoption of a single regional instrument that can be adapted to the local contexts based on in-depth qualitative cognitive research followed by quantitative confirmation of its psychometric properties. Brazil has learned from the experiences in other countries and there is much that other countries can learn from the national Brazilian experience, there the process that led to EBIA was strongly based on a multisectoral evidence-based policy oriented coalition that included community representatives, academicians, local, state and federal government officials, international agencies and nongovernmental organizations. This process not only led to the national adoption and application of EBIA, but also transformed the understanding of the food insecurity challenge faced by the country among stakeholders themselves and civil society in general.

\section{COLLABORATORS}

Both of the authors participated in the conceptualization of the manuscript. R. PÉREZESCAM ILLA took the leadership writing the first draft which was subsequently revised several times together with A.M. SEGALL-CORRÊA.

\section{REFERE N CES}

1. United Nations Organization. United Nations Special Rapporteur on the right to food [cited 2007 Feb 22]. Available from: <http://www. righttofood.org/>.

2. Frankenberger TR, Frankel L, Ross S, Burke M, Cardenas C, Clark D, et al. Household livelihood security: a unifying conceptual framew ork for CARE programs. Proceedings of the USAID workshop on performance measurement for food security, December 11-12, 1995; Arlington, VA. Washington (DC): United States Agency for International Development; 1997.

3. Food and Agriculture Organization. Measurement and assessment of food deprivation and undernutrition [cited $2007 \mathrm{Feb} 22$ ]. Available from: $<$ w w w.fao.org/DOCREP/005/Y 4249E/y4249 E00.htm>.

4. Townsend MS, Peerson J, Love B, Achterberg C, Murphy SP. Food insecurity is positively related to overweight in women. J Nutr. 2001; 131(6): 1738-45

5. Radimer K. Measurement of household food security in the USA and other industrialised countries. Public Health Nutr. 2002; 5(6A):859-64.

6. Webb P, Coates J, Frongillo EA, Rogers BL, Swindale $A$, Bilinsky P. M easuring household food insecurity: why it's so important and yet so difficult to do. J Nutr. 2006; 136(5):1404S-8S.

7. United States Department of Agriculture-USDA; Economic Research Service. Food Security/Hunger Core Module [cited 2005 May 27]. Available from: $<$ <ttp://www.ers.usda.gov/Briefing/FoodSecurity/ surveytools/core0699.pdf>.

8. Coates J, Frongillo EA, Rogers BL, Webb P, W ilde $P E$, Houser R. Commonalities in the experience of 
household food insecurity across cultures: what are measures missing? J Nutr. 2006; 136(5): 1438S-48S.

9. Segall-Corrêa AM, Pérez-Escamilla R, Marin-Leon L, Yuyama L, Vianna RPT, et al. Evaluation of household food insecurity in Brazil: validity assessment in diverse sociocultural settings. In: Ortega J, organizador. Iniciativa América Latina sin Hambre: articulos premiados en el dia Mundial de la Alimentación-2007. Available from: <http:// www.rlc.fao.org/iniciativa>.

10. Pérez-Escamilla R, Segall-Corrêa AM, Kurdian M aranha L, Sampaio MdF, M arin-Leon L, Panigassi $G$. An adapted version of the U.S. Department of Agriculture Food Insecurity module is a valid tool for assessing household food insecurity in Campinas, Brazil. J Nutr. 2004; v.134:1923-8.

11. Segall Corrêa AM, Pérez-Escamilla R, Archanjo Sampaio MF, M arín-León L, Panigassi G, Kurdian Maranha L. Acompanhamento e avaliação da segurança alimentar de famílias brasileiras: validação de metodologia e de instrumento de coleta de informação: urbano/rural. Campinas: Universidade Estadual de Campinas; 2004 [acesso 2007 out 12]. Disponível em: <http://www.opas. org.br/sistema/arquivos/vru_unic.pdf >.

12. Sampaio MFA, Kepple AW, Segall-Corrêa AM, Oliveira JTA, Panigassi G, Kurdian Maranha L. Segurança alimentar: experiência de grupos focais com populações rurais do Estado de São Paulo. Segur Alim Nutr (Campinas). 2006; 13(1):64-77.

13. Melgar-Quiñonez $H$, Nord M, Pérez-Escamilla R, Segall-Correa AM. Psychometric properties of a modified US household food security survey module in Campinas, Brazil. Eur J Clin Nutr. 2008; 62:665-73.

14. Instituto Brasileiro de Geografia e Estatística. Pesquisa Nacional por Amostra de Domicílios-
PNAD2004: suplemento de segurança alimentar. Rio de Janeiro.

15. Pérez-Escamilla R, Parás P, Dolkar T, MelgarQuiñonez $\mathrm{H}$. The USDA food security module is a valid tool for assessing household food insecurity in Mexico City. EB 2005 meetings, San Diego, California [Abstracts]. Faseb J. 2005; 19 (Part II):748.3.

16. Melgar-Quinonez HR, Zubieta AC, MkNelly B, Nteziyaremye A, Gerardo MF, Dunford C. Household food insecurity and food expenditure in Bolivia, Burkina Faso, and the Philippines. J Nutr. 2006; 136(6):1431S-7S.

17. Pérez-Escamilla R, Randolph S, Hathie I, Gaye I. Adaptation and validation of the USDA food security scale in rural Senegal [Abstract \# 104.1]. Faseb J. 2004; 18(Suppl):A106.

18. Melgar-Quinonez H, Zubieta AC, Valdez E, Whitelaw B, Kaiser $L$. Validation of an instrument to monitor food insecurity in Sierra de Manantlan, Jalisco Salud Publica Mex. 2005; 47(6):413-22.

19. Álvarez MC, Estrada A, Montoya EC, M elgarQuiñónez H. Validación de escala de la seguridad alimentaria doméstica en Antioquia, Colombia. Salud Publica Mex. 2006; 48(6):474-81.

20. Swindale A, Bilinsky P. Development of a universally applicable household food insecurity measurement tool: process, current status, and outstanding issues. J Nutr. 2006; 136(6): 1449S-52S.

21. United States Department of Agriculture-USDA; National Research Council. Food insecurity and hunger in the United States: an assessment of the measure. Washington (DC): The National Academies Press; 2006.

Received on: 6/3/2007

Resubmitted on: 16/10/2007

Approved on $8 / 5 / 2008$ 